agriTECH, 41 (1) 2021, 71-84

\title{
Effect of Nano and Bulk Nickel Oxide on Biomass and Antioxidant Enzymes Production of Fennel
}

\author{
Hilda Besharat ${ }^{1}$, Ramazan Ali Khavari-Nejad ${ }^{1}$, Homa Mahmoodzadeh ${ }^{2 *}$, \\ Khadijeh Nejad Shahrokh Abadi²
}

\author{
${ }^{1}$ Department of Biology, Science and Research Branch, Islamic Azad University, Tehran, Iran \\ ${ }^{2}$ Department of Biology, Mashhad Branch, Islamic Azad University, Mashhad, Iran \\ *Corresponding author: Homa Mahmoodzadeh, Email: mahmoodzadeh_h@yahoo.com
}

Submission: April 24, 2020; Revision: September 10, 2020; September 20, 2020; Acceptance: September 21, 2020

\begin{abstract}
The production, growth, and physiological processes of plants respond differently to the varying concentrations of nanoparticles. Due to the increasing importance and application of nanoparticles, it is essential to determine the impact on plants physiological systems. Therefore, this study investigated the effect of different bulk and nano nickel oxide concentrations on biomass production and the enzymatic system of fennel. The experiment was carried out in a completely randomized design with the applications of 5 replications and 5 concentrations $(0,20,100,400$, and $800 \mathrm{ppm})$ in the greenhouse of the Faculty of Science, Mashhad Branch, Islamic Azad University. This study analyzed various plants traits, including shoot and dry root weight and a few antioxidant enzymes. The results showed that root and shoot dry weight were not affected by the applied treatments. Furthermore, all applied levels of treatment significantly increased the activity of fennel leaf polyphenol oxidase compared to the control. The bulk treatment at $800 \mathrm{ppm}$ was exempted, where the application of bulk nickel oxide and nanoparticles decreased dehydrogenase enzyme activity. In addition, the activity of guaiacol peroxidase increased under all levels of treatments except $100 \mathrm{ppm}$ nanoparticles. The highest amount of phenylalanine ammonia-lyase activity was obtained under $20 \mathrm{ppm}$ treatment with a $61.98 \%$ increase compared to the control method. Furthermore, nickel oxide treatments also increased MDA. The results showed that nanomaterials' toxicity, caused oxidative stress in this plant, and the differences in MDA content of leaves explained the higher toxicity of NiO nanoparticles than bulk form. Moreover, higher activity of leaf antioxidative enzymes in bulk $\mathrm{NiO}_{2}$ treatments, especially Guaiacol Peroxidase, explained the plant's higher resistance to oxidative stress.
\end{abstract}

Keywords: Antioxidant enzymes; bulk nickel; fennel; malondialdehyde; nanoparticles; phenylalanine ammonialyase

\section{INTRODUCTION}

Nanotechnology is one of the most attractive branches of science with numerous applications in various fields, namely agriculture, industry, biotechnology, electronics, medicine, energy, life sciences, etc. (Tripathi et al., 2017; Tiwari et al., 2019; Nair \& Chung, 2014). Several studies have been carried out on nanoparticles due to their distinct physical and chemical properties, such as particle morphology, larger surface area, pore size, and high reactivity (Siddiqui et al., 2015). Currently, large amounts of these substances and their diverse applications are studied in various disciplines and industries. According to Tripathi et al. (2017), nanoparticles or their intermediate compounds have both positive and negative impacts on plants and animals. Most nanoparticles have been reported to have toxic effects even at very low concentrations, thereby affecting plants morphophysiological, biochemical, and molecular properties. However, some also have positive effects in enhancing plant growth and providing protection against various stresses (Syu et al., 2014; 
Rico et al., 2015; Tripathi et al., 2016). These effects tend to vary depending on the plant type, growth stage, physicochemical properties of the nanoparticles, and their amount under different conditions (Aghdam et al., 2016).

Generally, nickel oxide is one of the materials used in electroplating coatings to prevent the oxidation of metal surfaces and acts as a catalyst. Over the years, its application has been widely used as a transparent p-type semiconductor in optoelectronics, thin-layer sensors, light-emitting diodes, color-sensitive solar and fuel cells as electrochromic materials, which has been the focus of many studies. However, low concentrations of nickel play various essential roles in plants, bacteria, and fungi. Its deficiency in plants reduces growth, induces senescence, meristem, and leaf chlorosis, changes the nitrogen metabolism, and causes a decline in iron uptake. In addition, nickel is one of several metalloenzymes, such as urease, superoxide dismutase, nickel-iron hydrogenase, methyl-coenzyme M-reductase, and carbon monoxide hydrogenase, acetylcoenzyme A-synthase, A-hydrogenase and RNA (Ahmad \& Ashraf, 2012). A decrease in urease activity also disrupts nitrogen fixation and reduces the scavenging effect of superoxide free radicals. Nickel deficient plants accumulate toxic urea in the leaf tip due to reduced urease activity (Fageria et al., 2009). Irrespective of the fact that this element is metabolically important in plants, its high content in the soil or nutrient solutions is toxic to most species because it readily absorbs nickel. At the vegetative stage, high concentrations retard the growth of the shoot and roots. Subsequently, an increase in nickel affects the formation of branches, deformation of various parts, abnormal flowering, biomass reduction, disruption of root tip mitotic divisions, and iron deficiency induction, thereby leading to leaf chlorosis necrosis. In addition, excessive nickel affects nutrient uptake, inhibits metabolism, photosynthesis, and respiration, reduces plant quality and ultrastructural changes. Eventually, all these changes lead to reduced production due to the presence of high nickel levels (Ahmad \& Ashraf., 2012). The activities of antioxidant enzymes, namely catalase, ascorbate peroxidase, and superoxide dismutase, have been studied under nickel oxide treatment. It was discovered that catalase and superoxide dismutase enzyme activities in tomato plants were improved when treated with $2 \mathrm{mg} \mathrm{ml}^{-1}$ of nickel oxide (nanoparticle) (Faisal et al., 2013). An increase was also discovered in catalase activity in Bacopa monnieri when treated with $10 \mathrm{mg} \mathrm{l}^{-1}$ of silver nanoparticles (Krishnaraj et al., 2012). Furthermore, increased activity of this enzyme was detected in the roots, shoots, and leaves of Velvet mesquite (Prosopis velutina). On the contrary, increased ascorbate peroxidase activity was discovered only in the shoots and leaves (Hernandez-Viezcas et al., 2011). Ascorbyl palmitate-loaded chitosan inhibits the activity of polyphenol oxidase in banana plants. In addition, it was reported that the nanoparticle form of this compound is more effective in preventing enzyme activity (Kim et al., 2013). Bulk silicon and nanoparticles improve the activity of polyphenol oxidase in maize in the presence of pathogenic Fusarium sp. (Suriyaprabha et al., 2013). However, there is limited information concerning the effects and physiological changes induced by nickel oxide nanoparticles on medicinal plants.

Fennel plant (Foeniculum vulgare Mill.) is a perennial and aromatic medicinal substance found in the ubiquitous and indigenous Mediterranean region (Barros et al., 2010). This herb has various pharmacological uses and important in the food and cosmetics industries (Diao et al., 2014; Moser et al., 2014; Rather et al., 2016). In addition to essential oil, the fennel plant contains lipids and phytosterols used for commercial purposes (Barros et al., 2010; Nguyen et al., 2015). There have been numerous reports regarding the biological effects of essential oils, including the hepatoprotective, antioxidant, anti-tumor, anti-diabetic, anti-inflammatory, anti-fungal, antimicrobial, and antibacterial effects (Diao et al., 2014).

Medicinal plants have a variety of secondary metabolites used in the production of herbal medicines. Various studies have shown that nanoparticles improve the biosynthesis of these metabolites by inducing the plant defense system. Therefore, this research is a valuable step towards metabolite engineering and the production of herbal medicines.

Studies on the importance of antioxidant enzymes in protecting plant cells, the effect of nickel oxide nanoparticles on fennel, and its uses and availability in agriculture have never been studied. Therefore, this research was carried out to investigate the effect of bulk and nano nickel oxides on biomass and antioxidant enzyme production of fennel.

\section{MATERIALS AND METHODS}

\section{Experiment Details and Treatments}

This experiment was carried out to study the effect of nano and bulk nickel oxide on fennel plants' shoot and roots using a completely randomized design with 5 replications and concentrations $(0,20,100,400$, and $800 \mathrm{ppm}$ ). Each pot contained 10 fennel seeds planted at a depth of $1 \mathrm{~cm}$ and arranged in a greenhouse $\mathrm{w}$ irrigation conducted. The temperature varied between 25 and $30^{\circ} \mathrm{C}$ and on a daily photoperiod of 16 hours light 
and 8 hours of darkness with the seeds obtained from Pakan Isfahan Seed Company. The conventional shaker was used to obtain a uniform solution of nano-nickel oxide by placing it in an ultrasonic bath for 30 minutes before spraying it on the pots. $\mathrm{NiO}$ nanoparticles were obtained from the US Research Nanomaterials with the bulk derived from Merck. The required concentrations were poured into a wash bottle, with the foliar spray applied on a weekly basis, with the treatment process recorded each time. Subsequently, the treatments were freshly prepared before each application, with distilled water spray used as a control. The experiment lasted for 82 days, and a total of 5 foliar spray treatments were applied.

\section{Investigation of Nanoparticle Properties}

The investigation of nanoparticle properties such as particle motion, zeta potential, and bulk and nano nickel oxide sizes were performed with the Cordouan-Vasco Particle Size Analyzer using Nano Q software in Ferdowsi University of Mashhad. Conversely, the nanoparticles dissolved in a suitable solvent with deionized water at $\mathrm{pH}$ $=6$ were initially inserted into the ultrasonic apparatus used to create uniform scattering for 20 minutes at ambient temperature. After the nanoparticles were dispersed in the solvent, the sample was immediately transferred to a Zeta Sizer. This equipment determines the particle size by measuring the particles' Brownian motion in a sample, using Dynamic Light Scattering (DLS). In addition, the sizes are interpreted by applying proven theories with the crystalline properties of nickel oxide investigated using X-ray diffraction (XRD).

\section{Biomass Production}

To determine the biomass, each plant's total weight was measured using a weighing scale of 0.001 $\mathrm{g}$ precision (Sartorius TE2145srd=0.1 mg). The shoots and roots were further separated from the collar area and wrapped in aluminum foil, which was put in the oven at $70{ }^{\circ} \mathrm{C}$ for 72 hours to dry. Consequently, the shoot and root dry weights were measured using the same scale.

\section{Extraction of Soluble Leaf Proteins and Enzymatic Extract}

This experiment was carried out using $250 \mathrm{mg}$ of fresh leaf tissue and $1.5 \mathrm{ml}$ buffer extract (100 $\mathrm{mM}$ sodium phosphate buffer with an acidity of 7.4 ) pulverized in the cold (on the ice) Chinese mortar. All protein extraction steps were carried out at a temperature of $4{ }^{\circ} \mathrm{C}$. Immediately after the tissue's crushing and homogenization, the extract was poured into a microtiter and cooled for $13 \mathrm{~min}$ at $13,000 \mathrm{~g}$ and $4{ }^{\circ} \mathrm{C}$ (Vision VS-15000CFN II CE). The obtained supernatant was used to measure the soluble protein content and enzyme activity (Lee et al., 2012; Sunkar, 2010; MacAdam et al., 1992).

\section{Measurement of Enzyme and Malondialdehyde Polyphenol Oxidase Activities}

The measurement of polyphenol oxidase activity was carried out according to Raymond et al., 1993. A spectrometer was used to record the absorbance at 430 $\mathrm{nm}$ (Shimadzu UV/1100) and was finally calculated in terms of absorption changes per minute $\mathrm{mg}^{-1}$ leaf fresh weight ( $\Delta \mathrm{A}$ min $\left.\mathrm{mg} \mathrm{fw}^{-1}\right)$ (Kim and Kim, 2013).

\section{Guaiacol Peroxidase Activity}

The activities associated with Guaiacol peroxidase were in accordance with the research carried out by MacAdam et al. (1992), with the optical absorption changes recorded at $436 \mathrm{~nm}$ using a spectrophotometer (Shimadzu UV / 1100). The absorbance changes per minute $\mathrm{mg}^{-1}$ leaf fresh weight $\left(\Delta \mathrm{A}\right.$ min $\left.\mathrm{mg} \mathrm{fw}^{-1}\right)$ was also calculated based on MacAdam et al. (1992).

\section{Phenylalanine Ammonia Lyase (PAL)}

The amount of Phenylalanine Ammonia Lyase (PAL) was measured based on the enzyme's ability to convert phenylalanine to trans-cinnamic acid (BeaudoinEagan and Thorpe, 1989). The optical absorption of the samples was recorded at $290 \mathrm{~nm}$ with a Shimadzu UV/1100 spectrophotometer. Therefore, to determine the amount of PAL enzyme, a standard curve was drawn by generating different trans-cinnamic acid concentrations. Afterward, the content was calculated in $\mu \mathrm{g}$ of cinnamic acid produced per $\mathrm{g}$ of fresh leaf weight using the standard curve line equation, which is stated as follows $Y=0.07 X+0.01$, in which $Y$ is the optical absorption of the solution containing cinnamic acid and $X$ is the cinnamic acid concentration $\left(\mathrm{g} \mathrm{ml}^{-1} \mu\right)$.

\section{Dehydrogenase Enzyme}

The amount of dehydrogenase enzyme was measured by reducing the Triphenyl Tetrazolium Chloride (TTC) to Triphenyl Formazan (TPF). Conversely, $0.5 \mathrm{~g}$ of young roots were washed and dried before being measured. The roots were placed in tubes containing $2 \mathrm{ml}$ of $0.4 \%$ TTC $(0.4 \mathrm{~g} \mathrm{TTC}$ with $100 \mathrm{ml}$ distilled water) and $1 \mathrm{ml}$ of $0.06 \mathrm{~mol} \mathrm{l}^{-1}$ phosphate buffer with $7 \%$ acidity. They were then stored at $7^{\circ} \mathrm{C}$ for 3 hours (refrigerated). Subsequently, $1 \mathrm{ml}$ of $1 \mathrm{~mol} \mathrm{I}^{-1}$ sulfuric acid was added to the tubes, and TPF was formed. The optical absorption of the supernatant was immediately recorded at a wavelength of $485 \mathrm{~nm}$ (Wang et al., 2012). 


\section{MDA Content}

Lipid peroxidation was determined by measuring the MDA accumulation using Thiobarbituric acid based on the method proposed by Velikova et al. (2000). The crude extract was mixed with an equal volume of Thiobarbituric acid solution (5\% TBA) containing Trichloroacetic Acid (20\% TCA) and placed in a boiling bain-marie $\left(95^{\circ} \mathrm{C}\right)$ for $30 \mathrm{~min}$. However, it was rapidly cooled in an ice bain-marie. After centrifugation at $3000 \mathrm{rpm}$ for $5 \mathrm{~min}$, the absorbance of the sample was measured at 1 and $2 \mathrm{~nm}$ using a spectrophotometer (Shimadzu UV/1100). The MDA amount was calculated based on the difference in absorbance from 600 to 532 multiplied by the extinction coefficient of $1.55 \times 10^{5}$ in micromoles $\mathrm{g}^{-1}$ of fresh weight $\left(\mu \mathrm{mol} \mathrm{g} \mathrm{Fw}{ }^{-1}\right.$ ) (Poonam et al., 2013).

\section{Data Analysis}

This was carried out using SPSS software. Furthermore, the comparison of means was performed using ANOVA, while Duncan tests and graphs were prepared using MS Excel.

\section{RESULT AND DISCUSSION}

\section{Characters of Bulk and Nanoparticles of Nickel Oxide}

Figures 1 and 2 indicate the mobility and zeta potential of nanoparticles and bulk nickel oxides. The dielectric constant, mean particle mobility, and Zeta mean of the nickel oxide nanoparticles equaled 79.58, $0.58 \mu \mathrm{m} \mathrm{s}^{-1} \mathrm{~V}^{-1} \mathrm{~cm}^{-1}$, and $93.7 \mathrm{Mv}$, respectively. Subsequently, values of $79.44,-1.86$, and -25.10 were obtained for the bulk nickel oxide. Figures 3 and 4 show the nanoparticle and bulk nickel oxide sizes, measured with a nanoparticle sizer (D mean 47/36) and (D mean 220/92).
X-ray diffraction is a method for studying the crystal structure of materials, and it usually has a wavelength of approximately 0.5 to $2.5 \mathrm{~A}$. Electromagnetic radiation with a wavelength between 0.01 and $10 \mathrm{~nm}$ was used in carrying out this experiment. In addition, the wavelength is shorter than the UV and longer than the gamma-ray. According to the XRD results, the elements in the nickel oxide nanoparticles included nickel oxide and particles. There was also a single-phase within the bulk nickel oxide, as shown in Figure 5.

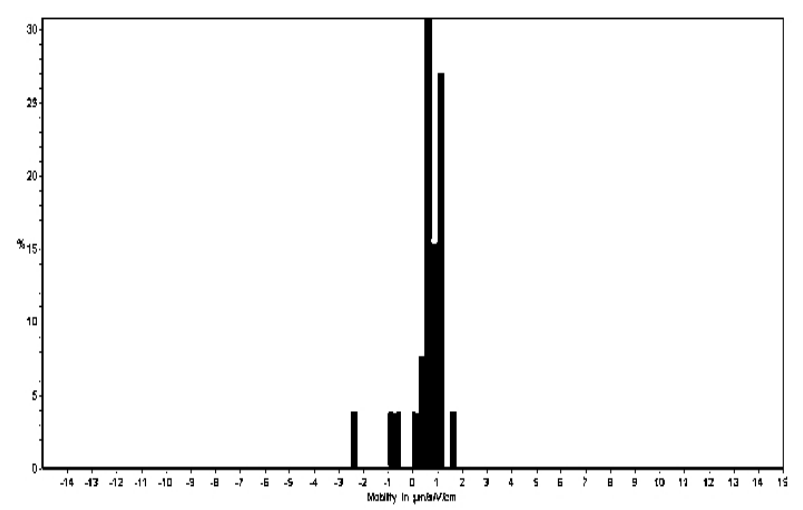

(A)

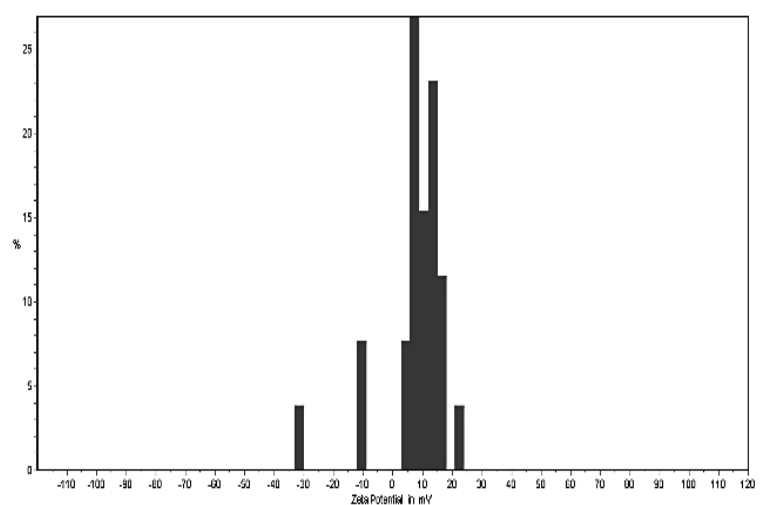

(B)

Figure 1. a) Particle motion and b) Zeta potential of nickel oxide nanoparticles using Zeta Sizer

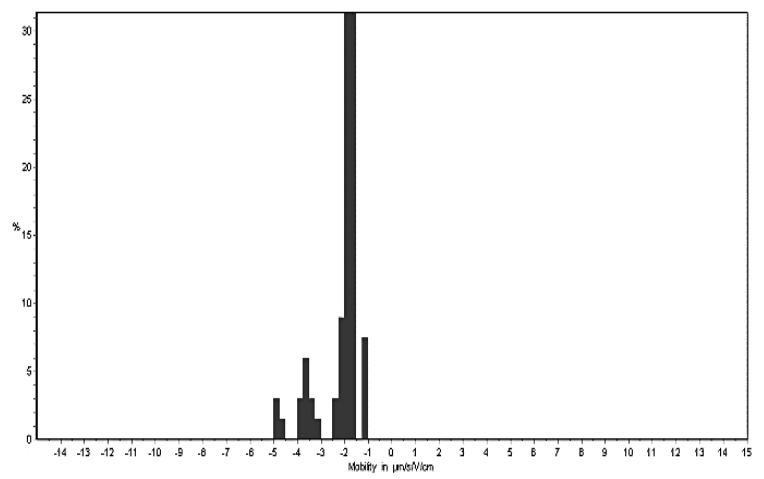

(a)

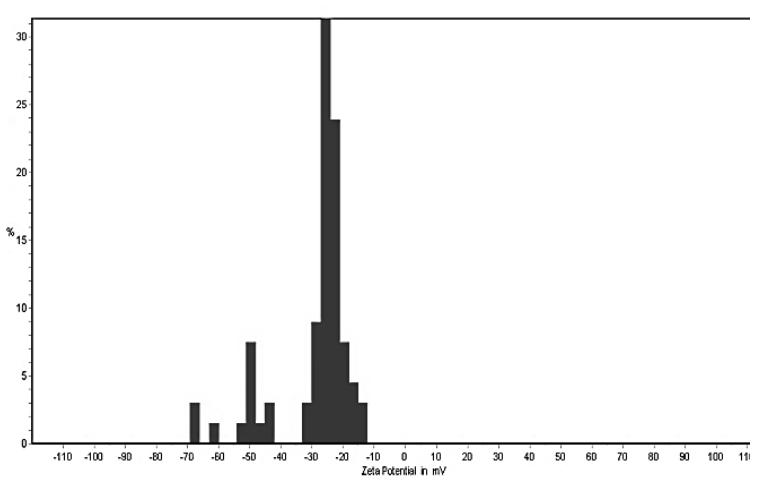

(b)

Figure 2. a) Particle motion and b) Zeta potential of nickel oxide bulk using Zeta Sizer 


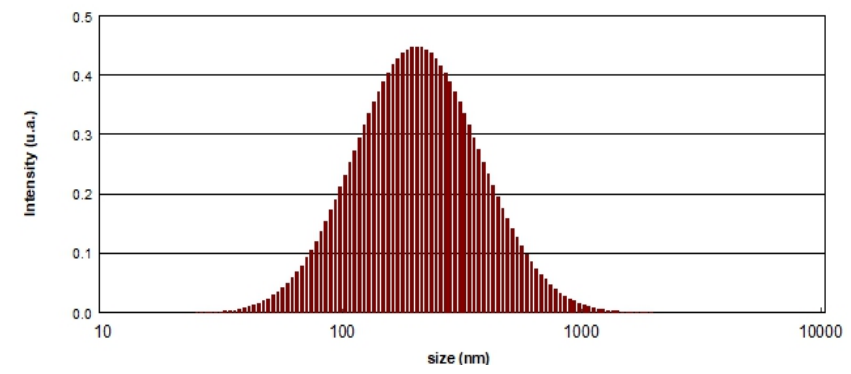

(A)

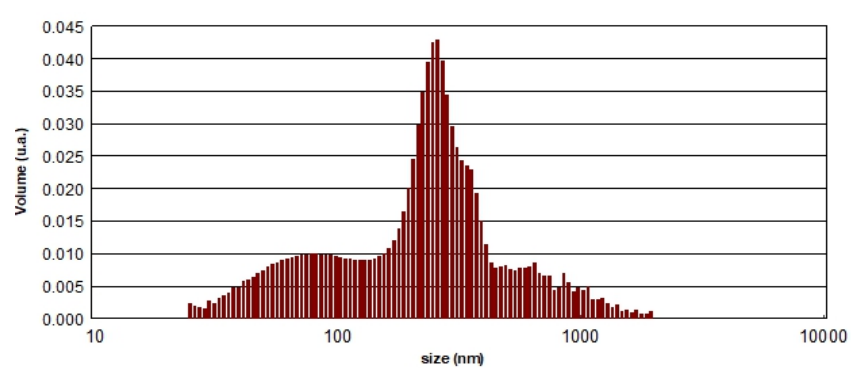

(B)

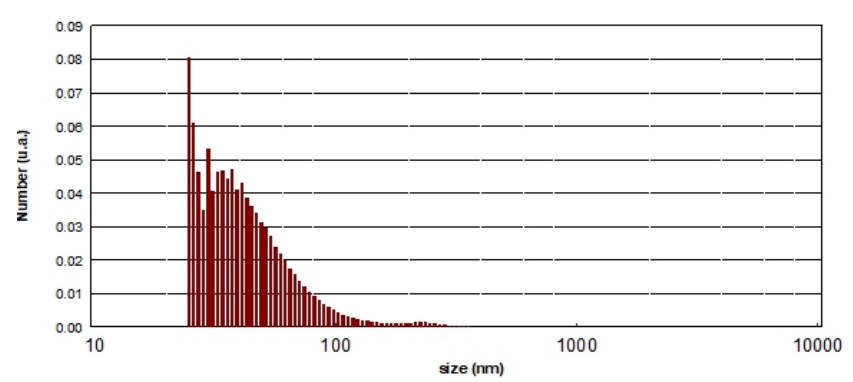

(C)

Figure 3. Size of nickel oxide nanoparticles measured with a nanoparticle sizer a) highly dispersed; b) scattered volume; c) dispersed number

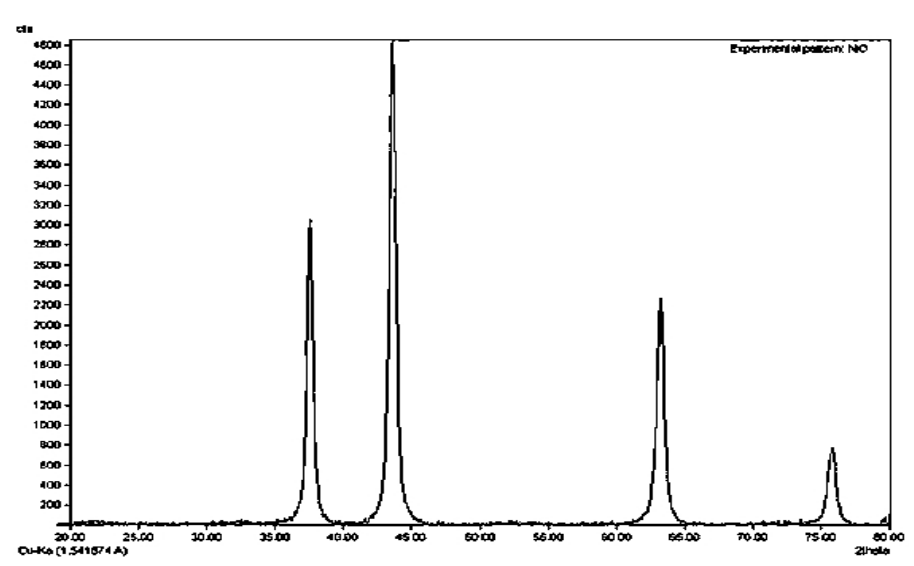

(A)

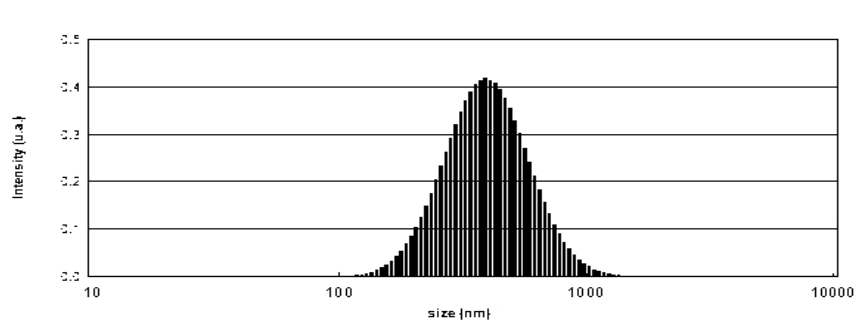

(A)

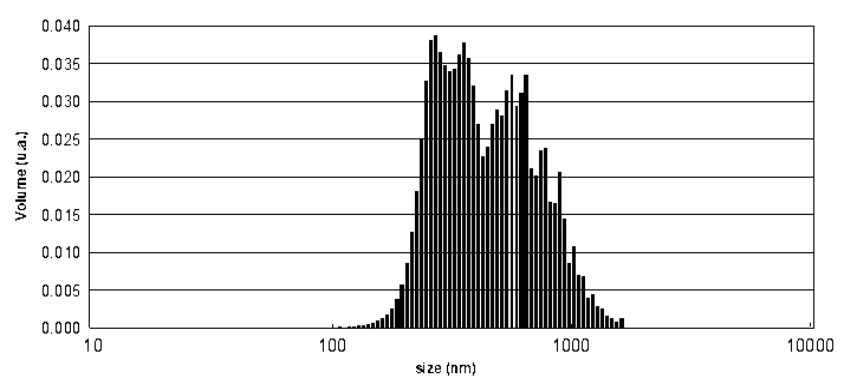

(B)

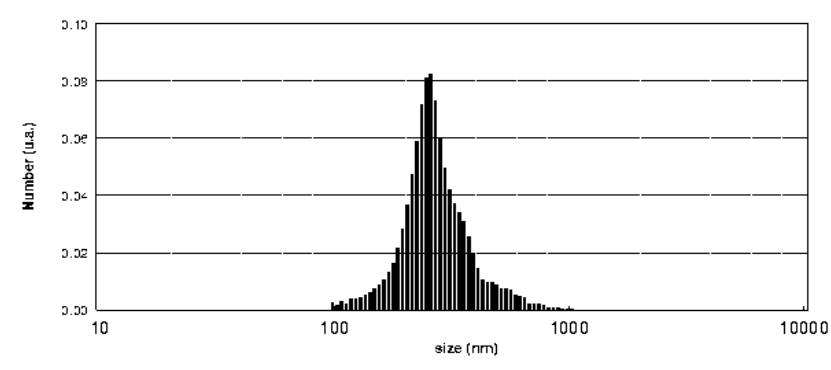

(C)

Figure 4. The bulk nickel oxide size measured with a nanoparticle sizer (a) highly dispersed; b) with scattered volume; $c$ ) with a scattered number

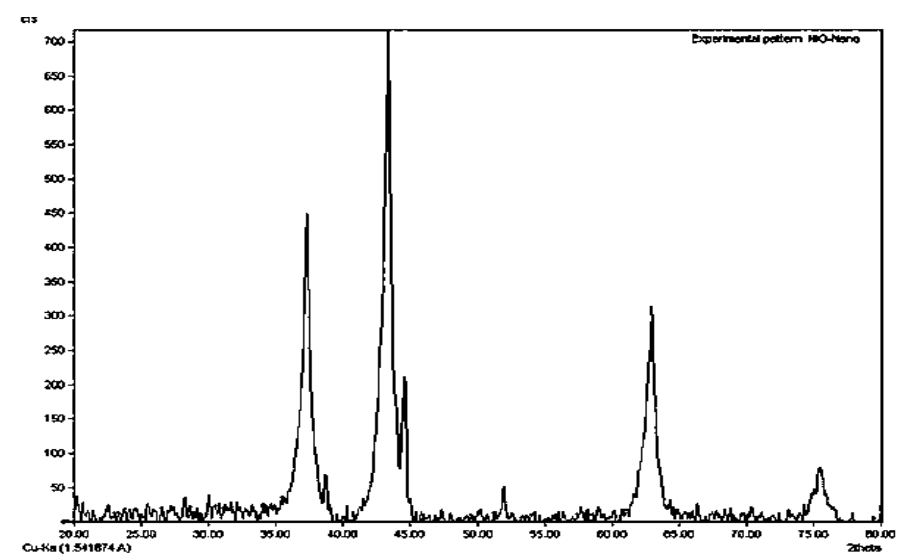

(B)

Figure 5. X-ray diffraction a) nickel oxide nanoparticles and b) bulk nickel oxide 


\section{Shoot and Root Biomass}

According to Table 1, the effect of different nanoparticle and bulk nickel oxide treatments was insignificant on root and shot dry weight of fennel $(p<$ 0.05 ). The mean comparison showed that all treatments had an insignificant difference compared to the control and all were in one statistical group.

The highest shoot dry weight was observed at 400 ppm treatment compared to the control, and the least was determined at $800 \mathrm{ppm}$ with $47 \%$ decrease, as shown in Fig 6. Based on several studies, the response of plants dry matter production to the application of various forms of essential elements is contradictory. The pore diameter of the plant cell wall is within the range of 5 to $20 \mathrm{~nm}$. The roots, which are the gateway to the nutrients, are extremely porous within the range of nanometers. The nanoparticles tend to be absorbed through these pores or by combining with transporter molecules or root exudates, including the use of endocytosis or ion channels (Rico et al., 2011). Nutrients uptake improvement had a positive effect on plant growth. According to Zhang et al. (2008), spraying titanium nanoparticles on cucumber leaves for several hours enhances photosynthesis, which in turn increases root growth. Chutipaijit (2015) stated that the application of nano titanium dioxide increases the metabolism and growth of rice crops. In contrast, increased concentrations of nanoparticles have a negative effect on the germination of some seeds, such as tobacco (Frazier et al., 2014) and meadow grasses (Azimi et al., 2014). This is indicated by the higher absorbance of nanoparticles by the seed coat,

Table 1. ANOVA analysis of studied traits

\begin{tabular}{|c|c|c|c|c|c|c|}
\hline \multicolumn{2}{|c|}{ Traits } & \multirow{2}{*}{$\begin{array}{c}\text { Sum of square } \\
.000\end{array}$} & \multirow{2}{*}{$\frac{\mathrm{df}}{8}$} & \multirow{2}{*}{$\begin{array}{c}\text { Mean Square } \\
.000\end{array}$} & \multirow{2}{*}{$\begin{array}{c}\mathrm{F} \\
.568\end{array}$} & \multirow{2}{*}{$\begin{array}{c}\text { P-value } \\
.791\end{array}$} \\
\hline & Between groups & & & & & \\
\hline \multirow[t]{3}{*}{ Root dry weight } & Within groups & .000 & 18 & .000 & & \\
\hline & Total & .000 & 26 & & & \\
\hline & Between groups & .033 & 8 & .003 & 13.72 & .025 \\
\hline \multirow[t]{3}{*}{ Shoot dry weight } & Within groups & .006 & 18 & .000 & & \\
\hline & Total & .039 & 26 & & & \\
\hline & Between groups & .004 & 8 & .000 & 6.005 & .001 \\
\hline \multirow{2}{*}{$\begin{array}{l}\text { Polyphenol oxidase } \\
\text { enzyme }\end{array}$} & Within groups & .001 & 18 & .000 & & \\
\hline & Total & .005 & 26 & & & \\
\hline \multirow{3}{*}{$\begin{array}{l}\text { Dehydrogenase } \\
\text { enzyme }\end{array}$} & Between groups & .073 & 8 & .009 & 3.220 & .019 \\
\hline & Within groups & .051 & 18 & .003 & & \\
\hline & Total & .123 & 26 & & & \\
\hline \multirow{3}{*}{$\begin{array}{l}\text { Guaiacol peroxidase } \\
\text { enzyme }\end{array}$} & Between groups & .168 & 8 & .021 & 4.142 & .006 \\
\hline & Within groups & .091 & 18 & .005 & & \\
\hline & Total & .260 & 26 & & & \\
\hline \multirow{3}{*}{$\begin{array}{l}\text { Phenylalanine } \\
\text { ammonia-lyase } \\
\text { enzyme }\end{array}$} & Between groups & 38.205 & 8 & 4.776 & 3.110 & .022 \\
\hline & Within groups & 27.636 & 18 & 1.535 & & \\
\hline & Total & 65.841 & 26 & & & \\
\hline \multirow{3}{*}{$\begin{array}{l}\text { Malondialdehyde } \\
\text { enzyme }\end{array}$} & Between groups & .008 & 8 & .001 & 2.700 & .038 \\
\hline & Within groups & .007 & 18 & .000 & & \\
\hline & Total & .015 & 26 & & & \\
\hline
\end{tabular}


thereby causing toxicity, decreases water absorption, germination, and seedling growth. Lee et al. (2012) reported that silver nanoparticles had no inhibitory effect on mung bean plants growth while zinc retarded sorghum growth. Furthermore, the response of plants to nanoparticles in agar medium is different from those in the soil. Ahmed (2016) studied the effect of nickel oxide nanoparticles on tomatoes at a concentration of $50 \mathrm{ppm}$ and found that it positively affects growth and biomass production. However, at $100 \mathrm{ppm}$, plant growth was retarded. In another study, inhibition of leaf proliferation and fresh weight loss was observed in Spirodela minor L. and Lemna minor L. algae under nanoparticles and bulk nickel oxide treatments (Torbati, 2018). Studies carried out on fennel, titanium dioxide nanoparticles caused a decline in plant growth and biomass production (Feizi et al., 2013). Yang and Watts (2005) stated that the effect of nano titanium dioxide had a toxic effect on the studied plants, such as radish, ryegrass, lettuce, maize, and cucumber, with inhibited root growth. Therefore, it is speculated that the uptake efficiency and nanoparticles' effect have varying impacts on different plants' growth and metabolic activities (Nair et al., 2010).

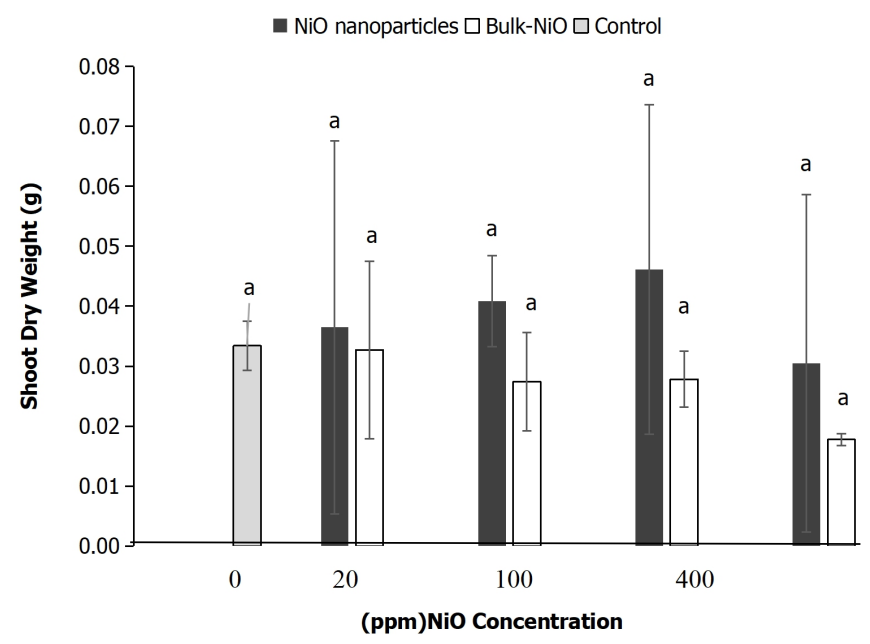

Figure 6. Comparison of the average shoot dry weight of fennel under different nanoparticles and bulk nickel oxide treatments

In another experiment, plants exposed to nanoparticles and bulk nickel oxide treatments did not show any signs of toxicity, including retarded shoot and root growth, deformed parts, abnormally shaped flowers, a decline in biomass production and germination, iron chlorosis as well as root and leaf necrosis (Ahmad \& Ashraf, 2012). Therefore, it was inferred that the fennel and those plants were able to withstand the varying concentrations of nickel. Some studies reported that anything above $10 \mathrm{mg} \mathrm{kg}^{-1}$ dry weight is regarded as a critical level of nickel in susceptible species (Kozlov, 2005), while for normal tolerant, it is less than $50 \mathrm{mg} \mathrm{kg}^{-1}$ dry weight (Asher, 1991) and $1000 \mathrm{mg} / \mathrm{kg}$ dry weight for hyper nickel accumulators (Pollard et al., 2002). Several factors, such as concentration and duration of nickel retention in the soil, cultivation conditions, growth stage, and plant species, affect plants' nickel toxicity (Gupta et al., 2008).

\section{Polyphenol Oxidase Activity}

Table 1 shows that the effect of different nanoparticle and bulk nickel oxide treatments on polyphenol oxidase activity was significant at $p<0.05$. The mean comparison in Figure 7 showed that all the treatments applied significantly increased polyphenol oxidase activity in fennel leaf compared with the control group. The least enzyme activity was observed in the control treatment, while the highest percentage of $134.37 \%$ was observed in $400 \mathrm{ppm}$ nickel nanoparticle treatment. Also, all concentrations of bulk and nanoparticles had an insignificant difference. However, high concentrations of nanoparticles showed more additive effect than the bulk application.

These enzymes are believed to be a resistance mechanism or an aspect of the process. According to various studies, antioxidant enzymes' activity is a biochemical marker used to predict the resistance to a variety of physicochemical and biological stresses. One of the most important biochemical changes in plants exposed to stress is the production of oxidizing molecules, which are the main causes of damages within the cell. These compounds are called reactive oxygen species (ROS) and tend to damage macromolecules and cellular organelles. ROSs reduces mitochondrial respiratory activity with the ability to stabilize carbon dioxide in chloroplasts as well as increase electrolyte leakage in the cell. It also aids in certain specific enzymes inactivation by oxidizing the amino acids in the proteins and the cofactors attached to them. They also damage the DNA molecule's sugars and bases and eliminate them, thereby causing mutations and various genetic effects. These compounds ultimately destroy pigments and other vital macromolecules of the plant as well as inhibits photosynthetic and respiratory processes (Gill \& Tuteja, 2010; Huang et al., 2012). ROS production and oxidative stress are mechanisms of metal nanoparticle toxicity (Ma et al., 2010). Cramer et al., (2011) stated that plant cells are protected against reactive oxygen species' damage by an enzymatic antioxidant defense system. Polyphenol oxidases are antioxidant enzymes present in plant cells. They are a group of copper- 


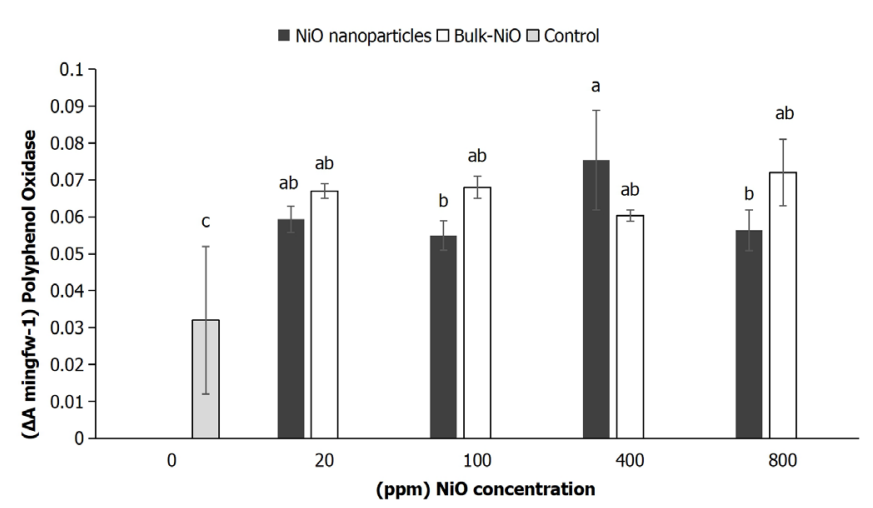

Figure 7. Activity of Fennel Polyphenol Oxidase under different nano and bulk Nickel Oxide treatments

containing proteins found in a wide range of organisms. These enzymes act as catalysts in reactions involving oxygen. The first reaction is the hydroxylation of mono phenols, which leads to the formation of O-dihydroxy phenols. On the contrary, the second reaction involves the oxidation of O-di compounds. However, it catalyzes hydroxyl phenols to quinones. Therefore, polyphenol oxidase oxidizes phenolic compounds and reduces the amount of these compounds in leaves and roots under stress. The altering of peroxidation kinetics causes a decrease in membrane fluidity and inhibits free radicals release, thereby improving the plant's resistance to stress (D'Souza \& Devaraj, 2013). This enzyme activity was maximal at a temperature of 40 and $50{ }^{\circ} \mathrm{C}$, while its inhibition was observed at $60{ }^{\circ} \mathrm{C}$ (Mizobutsi et al., 2010). Apparently, only a few studies have been carried out on the effect of nanoparticles and bulk nickel oxide on polyphenol oxidase activity in plants. Conversely, changes in the activities of other antioxidant enzymes, namely catalase, ascorbate peroxidase, and superoxide dismutase based on nickel oxide treatment, have been studied. The catalase and superoxide dismutase activities in tomato plants treated with $2 \mathrm{mg} \mathrm{ml}^{-1}$ of nanoparticle nickel oxide showed an increase of 6.8 and 1.7, respectively (Faisal et al., 2013). Krishnaraj et al. (2012) stated that an increase was detected in catalase activity (Bacopa monnieri) when $10 \mathrm{mg} \mathrm{l}^{-1}$ of silver nanoparticles were added. In accordance with the study carried out on the effect of nano-oxide on Velvet mesquite (Prosopis velutina). It was discovered that catalase activity increased in the roots, shoots, and leaves, with a rise in ascorbate peroxidase in shoots and leaves (Hernandez-Viezcas et al., 2011). Ascorbyl palmitate-loaded chitosan nanoparticles were also discovered to inhibit polyphenol oxidase activity in the banana plant. It was reported that the nanoparticle form of this compound was more effective in preventing enzyme activity (Kim et al., 2013). The application of silicon in bulk and nanoparticles on maize plants in the presence of pathogenic Fusarium sp. showed that the polyphenol oxidase activity was higher in the nanoparticle treatment than the bulk form (Suriyaprabha et al., 2013). In this study, a significant increase in polyphenol oxidase activity was observed across all nickel oxide treatments compared to the control.

\section{Dehydrogenase Enzyme}

According to Table 1, the effect of different nano and bulk nickel oxide treatments on dehydrogenase enzyme was reported to be significant at $p<0.05$. The mean comparison showed that the application of nickel oxide both in bulk and nanoparticles decreased this enzyme activity. The only exception was the 800 ppm bulk treatment shown in figure 8 . Also, all the treatments except 20 ppm and 400 ppm of the bulk, including 800 ppm of nano nickel, had an insignificant difference compared to the control treatment. The highest amount of enzyme was observed at a concentration of 800 ppm treatment while the least was detected at $20 \mathrm{ppm}$ and was $59.49 \%$ lower than the control group. The activity of dehydrogenase enzyme at 800 ppm bulk was significantly higher than a similar concentration of nanoparticles. However, at concentrations of 20, 100, and 400 ppm, the amount of dehydrogenase enzyme was observed to be higher when nickel oxide nanoparticle was used (Figure 8). Dehydrogenases are a group of biological enzymes classified according to the reaction type, except oxidoreductases and catalyze oxidation-reduction processes. They are involved in biological cycles and synthesis pathways of various compounds present in plants. For example, pyruvate, malate, isocitrate, succinate, and alpha-ketoglutarate are dehydrogenases present in the TCA cycle. NAD (P) $\mathrm{H}$ dehydrogenase is also an enzyme in the electron transport chain that plays an important role in the production of ATP. Glucose-6-phosphate in the pentose phosphate pathway, glyceraldehyde-3-phosphate, and malate in the Calvin and glyoxylate cycles, respectively as well as glutamate, are also involved in ammonium fixation. Alcohol and lactate dehydrogenases are anaerobic respiratory enzymes. The increased activity of two enzymes, namely betaine aldehyde and glyceraldehyde-3-phosphate dehydrogenases, in plants exposed to stress has also been reported. Shikimate 3-dehydrogenase is also involved in the Shikimate pathway, which is important in secondary metabolites' biosynthesis (Taiz et al., 2015). Studies have shown that $\mathrm{NAD}^{+}$and $\mathrm{NADP}^{+}$are better coenzymes or substrates of dehydrogenase enzymes (Curien et al., 2005). Moreover, due to their importance, the effect of nanoparticles has received little attention. Wang et al. (2012) researched 


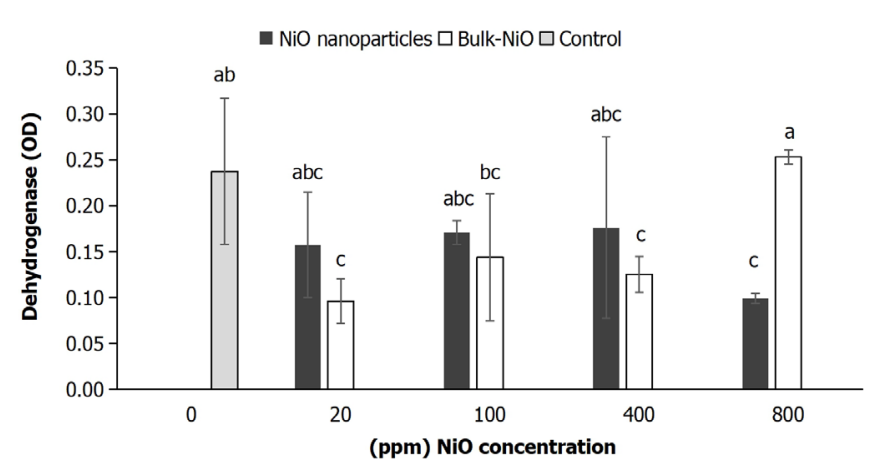

Figure 8. The amount of fennel root dehydrogenase enzyme under different nano and bulk nickel oxide treatments

the effect of oxidized multiwalled carbon nanotubes on wheat plants and found an increase in dehydrogenase's electron transfer reactions. Kumar et al. (2012) stated that plants affected by titanium dioxide nanoparticles also have increased dehydrogenase activity, responsible for water uptake and increased production of biomass. It is believed that this enzyme also regulates the uptake of substances. Dehydrogenase activity is an important indicator of root viability. Several studies have stated the role of this enzyme in water uptake and improvement of plant growth (Wei et al., 2010). It is reported that the effect of nickel at a concentration of $0.5-0.5 \mathrm{mM}$ decreased the dehydrogenase enzyme in pea (Seregin \& Kozhevnikova, 2006), which is in line with the results of this study as well.

Heavy metals directly inhibit enzymes such as dehydrogenase by interacting with the protein $\mathrm{SH}$ groups and change the protein conformation, thereby leading to the inactivation of the enzymes. Presently, hundreds of enzymes are known to be inhibited by $\mathrm{SH}$ group binding, with concomitant metabolic disorders. All these data led to the conclusion that, at high $\mathrm{Ni}$ concentrations, most enzyme activities tend to diminish. On the contrary, some of them, particularly those of antioxidant enzymes, increased. In most cases, it is unknown whether these changes in enzyme activities stem directly from $\mathrm{Ni}^{2+}$ effects, such as binding to $\mathrm{SH}-$ groups, histidine, displacing the metals from metalenzyme active centers, or indirectly, when mediated by the chain of reactions that affect the expression of the corresponding genes or exhaust their substrate pools. The inhibition of enzyme activities by heavy metals is one of the causes of declining cell metabolism (Seregin \& Kozhevnikova, 2006), as reported in this research.

\section{Activity of Guaiacol Peroxidase}

Table 1 shows that the effect of different nano and bulk nickel oxide treatments on foliar guaiacol peroxidase activity was significant at $p<0.05$. The means comparison showed that there was an increased activity of this enzyme across all treatments except that which was with a concentration of $100 \mathrm{ppm}$ nanoparticle, as shown in Figure 9. However, the increase in value varies with the different levels of treatment. The highest amount of enzyme activity compared to control was observed in 800 and 20 ppm bulk treatments, which statistically remained in one group. The least enzyme activity was observed in the 100 ppm treatment, which was $18 \%$ less than the control (Figure 9). Guaiacol peroxidase is one of the antioxidant enzymes involved in detoxifying a variety of reactive oxygen species (D'Souza \& Devaraj, 2013). The hydrogen peroxide in this enzyme serves as an electron acceptor, thereby resulting in the oxidized donor reaction, which produces water (Saeidian \& Ghasemifar, 2013). In addition, it belongs to the group of peroxidase enzymes. Generally, it catalyzes the oxidation and reduction reaction between $\mathrm{H}_{2} \mathrm{O}_{2}$, which acts as the electron acceptor, and many other types of substrates. The presence of peroxidase at various cellular sites such as the nucleus, mitochondria, ribosomes, walls, and membranes has been established. This compound forms the initial defense of the plant. Increased peroxidase activity has been observed following exposure to a variety of stresses. The level of hydrogen peroxide in the cell is regulated by a range of enzymes, including catalase and peroxidase. These enzymes are involved in several biological processes, and their increased activity in plants indicates the initiation of their defense mechanisms against stress (Smirnova et al., 2010). Torbati (2018) carried out a research which involves increased concentrations of nano and bulk nickel oxide in algae Spirodela minor L. and Lemna minor L. It was concluded that nano nickel oxide, particularly at high concentrations, has more negative effects than the bulk. Increased activity of guaiacol peroxidase was also reported in plants treated with high concentrations of bulk copper (Yruela, 2005). Furthermore, increased activity of oxidase and peroxidase enzymes was also observed in plants treated with multiwalled carbon nanotubes due to the cell wall's interaction (khodakovskaya et al., 2012). In an experimental study, the effect of approximately 1 to $40 \mathrm{mM}$ of nickel increased peroxidase activity in wheat (Seregin \& Kozhevnikova, 2006). Krishnaraj et al. (2012) stated that the increased activity of guaiacol peroxidase was discovered in Bacopa monnieri when treated with silver nanoparticles. These results are consistent with this study, and it was concluded that increasing the activity of guaiacol peroxidase is a type of plant defense mechanism against stress. 


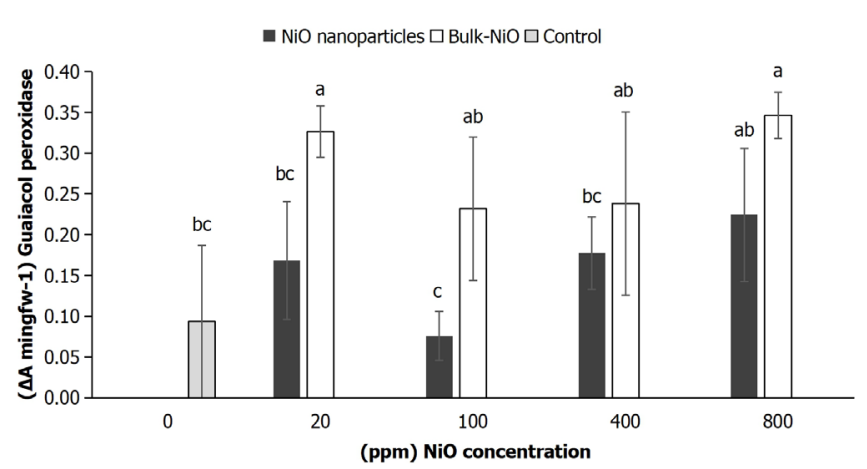

Figure 9. Activity of leaf Guaiacol Peroxidase activity under different nano and bulk Nickel Oxide treatments

\section{Phenylalanine Ammonia Lyase}

Table 1 shows that the effect of different nano and bulk nickel oxide treatments on the amount of phenylalanine ammonia-lyase in fennel was significant at $\mathrm{P}<0.05$. Comparing the mean showed that the highest amount of enzyme activity was realized from the 20 ppm bulk, which showed a $61.98 \%$ increase compared to the control (Fig 10). Enzyme activity in all treatments except the 20 ppm was insignificantly different from the control group (Fig 10). It was also lower in Ni and NPs at 100, 400, and 800 ppm treatments, while no trend was observed at 20 ppm (Fig 10). The phenylpropanoid pathway starts with phenylalanine degradation, which is catalyzed by phenylalanine ammonia-lyase (PAL). This pathway leads to the formation of various derivatives such as phenolic, lignin, suberin, flavonoids, isoflavonoids, coumarins, and soluble esters, many of which are involved in defense responses. This enzyme activity is affected by a number of factors such as light, temperature, growth regulators, inhibitors of protein and RNA synthesis, wounds, including mineral nutrition. It also plays an important role in the production of secondary metabolites. Therefore, it is necessary to study its activity in medicinal plants. Torbati (2018) reported that the treatment of two plant species with 10 and $50 \mathrm{mg} \mathrm{L}^{-1}$ of nano and bulk nickel oxide respectively, significantly increased flavonoids. Subsequently, an increase in the amount of flavonoids was observed in Brassica nigra after it was treated with ZnO nanoparticles (Zafar et al., 2016). The results of these experiments are consistent with the present study. Suriyaprabha et al. (2013) stated that the effect of bulk and nano silicon on phenylalanine ammonia-lyase activity contained in corn was prohibited with increasing concentration of nanoparticles compared to control. However, with silicon application, it was insignificantly different from the control.

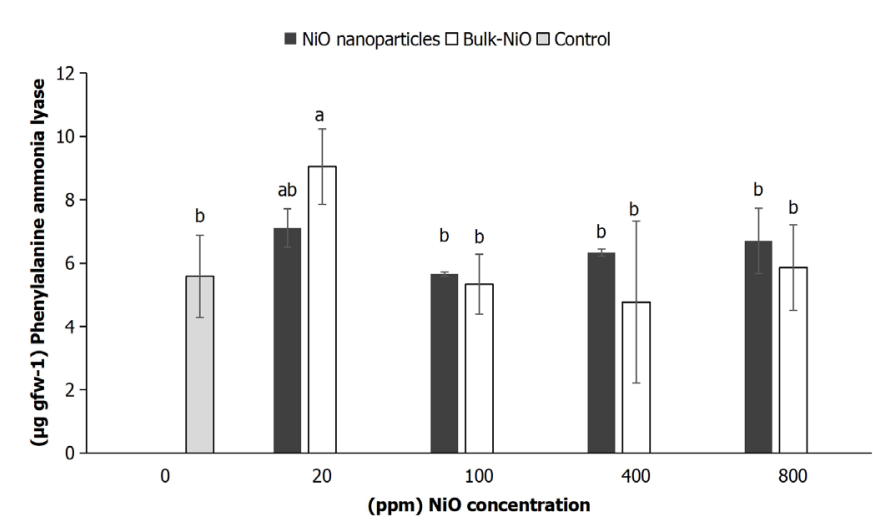

Figure 10. Amount of Phenylalanine Ammonia Lyase of Fennel under different nano and bulk nickel oxide treatments

\section{Malondialdehyde Content}

According to Table 1, the effect of different nano and bulk nickel oxide treatments on the amount of malondialdehyde was insignificant at $p<0.05$. The means comparison showed that the highest amount of this enzyme was obtained at 20 and $800 \mathrm{ppm}$ nickel oxide treatments, which were increased by $68 \%$ and 61 $\%$, respectively, when compared with the control (Figure 11). The least level of malondialdehyde was observed at 20 ppm bulk, which was decreased by $63 \%$. Based on all the nickel oxide concentrations, the amount of malondialdehyde in the nano form was higher than the bulk (Figure 11). Oxygen-free radicals produce aldehydes such as MDA by peroxidation of unsaturated fatty acids. As a result of lipid peroxidation, there was an increase in permeability, and membrane destruction, which led to the occurrence of cell death (Gill \& Tuteja, 2010). MDA content is the second end product of unsaturated fatty acid oxidation, and it is generally used as a measure of lipid peroxidation, which acts as an indicator of oxidative stress to assess the extent of membrane damage under such conditions (Watanabe et al., 2000). Investigating the effect of nano nickel oxide in accordance with acetaminophen at concentrations of 0 to $1000 \mathrm{mg}$ $\mathrm{kg}^{-1}$ on barley showed an increase in nanoparticle concentration, membrane lipid peroxidation, and MDA content (Soares et al., 2016). Torbati (2018) stated that MDA levels increased with increasing concentrations of nano nickel oxide $\left(50 \mathrm{mg} \mathrm{L}^{-1}\right)$ in algae (Spirodela minor L.) and Lemna minor L. However, a similar concentration of bulk nickel oxide only increased the MDA in algae (Spirodela minor L.). According to Faisal et al. (2013), lipid peroxidation activity was 2.7 times higher than the control at a concentration of $2 \mathrm{mg} / \mathrm{ml}$ nano-nickel oxide. The production of malondialdehyde by different 
nanoparticles has been reported in numerous plants under various stresses (Saison et al., 2010). This study discovered that nano nickel oxide treatments also increased MDA compared to the control group. This was due to increased oxidative stress and lipid peroxidation. MDA levels indicate ROS accumulation and the invasion of these molecules into the membrane due to plant toxicity by pollutants (Tarrahi et al., 2017).

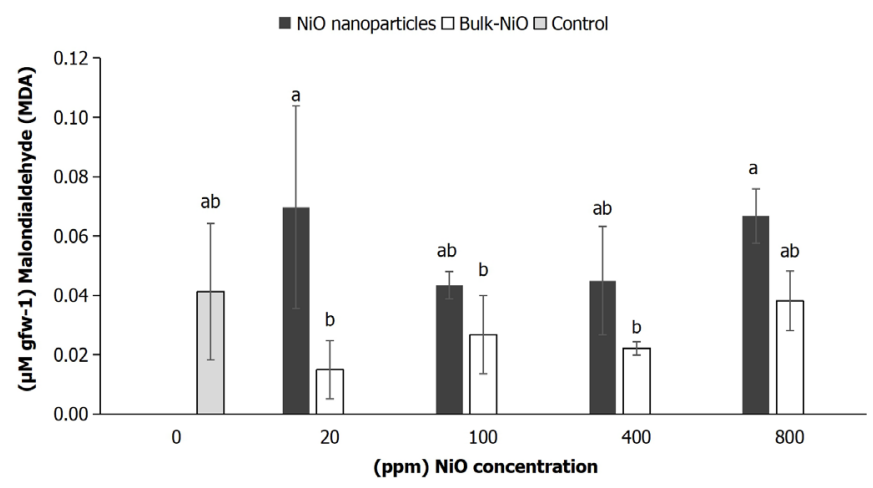

Figure 11. Malondialdehyde content of fennel plant under different nano and bulk nickel oxide treatments

\section{CONCLUSION}

Based on this study, the treatment with bulk and nano nickel oxide did not affect the biomass production (shoot and root) in the fennel. Furthermore, by examining the activities of important antioxidant enzymes and membrane lipid peroxidation index, it was stated that the treatment with nano and bulk nickel oxide had a stimulating effect on polyphenol oxidase, guaiacol peroxidase, and phenylalanine ammonia-lyase. In contrast, there was a decrease in the amount of dehydrogenase enzyme in the root and an increase in the lipid peroxidation of nickel oxide treatments. However, the response to the bulk and nano forms was different. The results suggested that nanotoxicity caused oxidative stress in this plant, while the differences in MDA content of the leaves imply an increase in $\mathrm{NiO}$ nanoparticles' toxicity. Moreover, higher activity of leaf antioxidative enzymes in bulk $\mathrm{NiO}_{2}$ treatments, particularly Guaiacol Peroxidase, depicts increased resistance of the plant to oxidative stress.

\section{CONFLICT OF INTEREST}

The authors declared no conflict of interest.

\section{REFERENCES}

Aghdam, M.T.B., Mohammadi, H., \& Ghorbanpour, M. (2016). Effects of Nano particulate anatase titanium dioxide on physiological and biochemical performance of (Linum usitatissimum) (Linaceae) under well-watered and drought stress conditions. Brazilian Journal of Botany, 39(1), pp.139-146. https://doi.org/10.1007/s40415015-0227-x

Ahmad, M.S.A., \& Ashraf, M. (2012). Essential roles and hazardous effects of nickel in plants. In Reviews of environmental contamination and toxicology, (pp. 125-167). Springer, New York, NY. https://doi. org/10.1007/978-1-4614-0668-6_6

Ahmed, A.I., Yadav, D.R., \& Lee, Y.S. (2016). Applications of nickel nanoparticles for control of Fusarium wilt on lettuce and tomato. Int J Innov Res Sci Eng Technol, 5, zpp.7378-7385. https://www.semanticscholar.org/paper

Asher, C.J. (1991). Beneficial elements, functional nutrients, and possible new essential elements. Micronutrients in agriculture, 4 pp.703-723. https://doi.org/10.2136/ sssabookser4.2ed.c18

Azimi, R., Jankju Borzelabad, M., Feizi, H., \& Azimi, A. (2014). Interaction of $\mathrm{SiO}_{2}$ nanoparticles with seed prechilling on germination and early seedling growth of tall wheatgrass (Agropyron elongatum L.). Polish Journal of Chemical Technology, 16(3) pp.25-29. https://doi.org/10.2478/ pjct-2014-0045

Barros, L., Carvalho, A.M., \& Ferreira, I.C. (2010). The nutritional composition of fennel (Foeniculum vulgare): Shoots, leaves, stems and inflorescences. LWT-Food Science and Technology, 43(5), pp.814-818. https://doi. org/10.1016/j.lwt.2010.01.010

Beaudoin-Eagan, L.D., \& Thorpe, T.A. (1985). Tyrosine and phenylalanine ammonia lyase activities during shoot initiation in tobacco callus cultures. Plant Physiology, 78(3), pp.438-441. https://doi.org/10.1104/pp.78.3.438

Chutipaijit, S. (2015). Establishment of condition and nano particle factors influencing plant regeneration from aromatic rice (Oryza sativa). International Journal of Agriculture \& Biology, 17 pp.1049-1054. https:// web.b.ebscohost.com

Cramer, G.R., Urano, K., Delrot, S., Pezzotti, M., \& Shinozaki, K. (2011). Effects of abiotic stress on plants: a systems biology perspective. BMC plant biology, 11(1), pp.163. https://doi.org/10.1186/1471-2229-11-163

Curien, G., Ravanel, S., Robert, M., \& Dumas, R. (2005). Identification of Six Novel Allosteric Effectors of Arabidopsis thaliana Aspartate Kinase-Homoserine Dehydrogenase Isoforms Physiological Context Sets the Specificity. Journal of Biological Chemistry, 280(50), pp.41178-41183. https://www.jbc.org/ content/280/50/41178.short

D'Souza, M.R., \& Devaraj, V.R. (2013). Oxidative stress biomarkers and metabolic changes associated with 
cadmium stress in hyacinth bean (Lablab Purpureus). African Journal of Biotechnology, 12(29). DOI: 10.5897/ AJB2013.12385

Diao, W.R., Hu, Q.P., Zhang, H., \& Xu, J.G. (2014). Chemical composition, antibacterial activity and mechanism of action of essential oil from seeds of fennel (Foeniculum vulgare Mill.). Food Control, 35(1), pp.109-116. https:// doi.org/10.1016/j.foodcont.2013.06.056

Fageria, N.K., Filho, M.B., Moreira, A., \& Guimarães, C.M. (2009). Foliar fertilization of crop plants. Journal of plant nutrition, 32(6), pp.1044-1064. https://doi. org/10.1080/01904160902872826

Faisal, M., Saquib, Q., Alatar, A.A., Al-Khedhairy, A.A., Hegazy, A.K., \& Musarrat, J. (2013). Phytotoxic hazards of NiOnanoparticles in tomato: a study on mechanism of cell death. Journal of hazardous materials, 250, pp.318-332. https://doi.org/10.1016/j.jhazmat.2013.01.063

Feizi, H., Kamali, M., Jafari, L., \& Moghaddam, P.R. (2013). Phytotoxicity and stimulatory impacts of nanosized and bulk titanium dioxide on fennel (Foeniculum vulgare Mill). Chemosphere, 91(4), pp.506-511. https://doi. org/10.1016/j.chemosphere.2012.12.012

Frazier, T.P., Burklew, C.E., \& Zhang, B. (2014). Titanium dioxide nanoparticles affect the growth and microRNA expression of tobacco (Nicotiana tabacum). Functional \& integrative genomics, 14(1), pp.75-83. https://doi. org/10.1007/s10142-013-0341-4

Gill, S.S., \& Tuteja, N. (2010). Reactive oxygen species and antioxidant machinery in abiotic stress tolerance in crop plants. Plant physiologyand biochemistry, 48(12), pp.909930. https://doi.org/10.1016/j.plaphy.2010.08.016

Gupta, U.C., Kening, W.U., \& Liang, S. (2008). Micronutrients in soils, crops, and livestock. Earth Science Frontiers, 15(5), pp.110-125. https://doi.org/10.1016/S18725791(09)60003-8

Hernandez-Viezcas, J.A., Castillo-Michel, H., Servin, A.D., Peralta-Videa, J.R., \& Gardea-Torresdey, J.L. (2011). Spectroscopic verification of zinc absorption and distribution in the desert plant Prosopis juliflora-velutina (velvet mesquite) treated with $\mathrm{ZnO}$ nanoparticles. Chemical engineering journal, 170(2-3), pp.346-352. https://doi.org/10.1016/j.cej.2010.12.021

Huang, J., Sun, S., Xu, D., Lan, H., Sun, H., Wang, Z., Bao, Y., Wang, J., Tang, H., \& Zhang, H. (2012). A TFIIIAtype zinc finger protein confers multiple abiotic stress tolerances in transgenic rice (Oryza sativa L.). Plant molecular biology, 80(3), pp.337-350. https://doi. org/10.1007/s11103-012-9955-5

Khodakovskaya, M.V., De Silva, K., Biris, A.S., Dervishi, E., \& Villagarcia, H. (2012). Carbon nanotubes induce growth enhancement of tobacco cells. ACS nano, 6(3), pp.21282135. https://doi.org/10.1021/nn204643g
Kim, J.J., \& Kim, W.Y. (2013). Purification and characterization of polyphenol oxidase from fresh ginseng. Journal of ginseng research, 37(1), p.117-123. https://www. ncbi.nlm.nih.gov/pmc/articles/PMC3659630/pdf/ grosbr-37-117.pdf

Kim, M.K., Lee, J.S., Kim, K.Y., \& Lee, H.G. (2013). Ascorbyl palmitate-loaded chitosan nanoparticles: characteristic and polyphenol oxidase inhibitory activity. Colloids and Surfaces B: Biointerfaces, 103, pp.391-394. https://doi. org/10.1016/j.colsurfb.2012.09.038

Kozlov, M.V. (2005). Pollution resistance of mountain birch, (Betula pubescens) subsp. czerepanovii, near the copper-nickel smelter: natural selection or phenotypic acclimation? Chemosphere, 59(2), pp.189-197. https:// doi.org/10.1016/j.chemosphere.2004.11.010

Krishnaraj, C., Jagan, E.G., Ramachandran, R., Abirami, S.M., Mohan, N., \& Kalaichelvan, P.T. (2012). Effect of biologically synthesized silver nanoparticles on (Bacopa monnieri) (Linn.) Wettst. plant growth metabolism. Process biochemistry, 47(4), pp.651-658. https://doi. org/10.1016/j.procbio.2012.01.006

Kumar, V., Kumari, A., Guleria, P., \& Yadav, S.K. (2012). Evaluating the toxicity of selected types of nanochemicals. In Reviews of environmental contamination and toxicology (pp. 39-121). Springer, New York, NY. https://doi.org/10.1007/978-1-4614-1463-6_2

Lee, W.M., Kwak, J.I., \& An, Y.J. (2012). Effect of silver nanoparticles in crop plants Phaseolus radiatus and Sorghum bicolor: media effect on phytotoxicity. Chemosphere, 86(5), pp.491-499. https://doi. org/10.1016/j.chemosphere.2011.10.013

Ma, Y., Kuang, L., He, X., Bai, W., Ding, Y., Zhang, Z., Zhao, Y., \& Chai, Z. (2010). Effects of rare earth oxide nanoparticles on root elongation of plants. Chemosphere, 78(3), pp.273-279. https://doi.org/10.1016/j. chemosphere.2009.10.050

MacAdam, J.W., Nelson, C.J., \& Sharp, R.E. (1992). Peroxidase activity in the leaf elongation zone of tall fescue: I. Spatial distribution of ionically bound peroxidase activity in genotypes differing in length of the elongation zone. Plant Physiology, 99(3), pp.872-878. https://doi. org/10.1104/pp.99.3.872

Mizobutsi, G.P., Finger, F.L., Ribeiro, R.A., Puschmann, R., Neves, L.L.D.M., \& Mota, W.F.D. (2010). Effect of $\mathrm{pH}$ and temperature on peroxidase and polyphenol oxidase activities of litchi pericarp. Scientia Agricola, 67(2), pp.213-217. https://doi.org/10.1590/S010390162010000200013

Moser, B.R., Zheljazkov, V.D., Bakota, E.L., Evangelista, R.L., Gawde, A., Cantrell, C.L., Winkler-Moser, J.K., Hristov, A.N., Astatkie, T., \& Jeliazkova, E. (2014). Method for obtaining three products with different properties from 
fennel (Foeniculum vulgare) seed. Industrial crops and products, 60, pp.335-342. https://doi.org/10.1016/j. indcrop.2014.06.017

Nair, P.M.G., \& Chung, I.M. (2014). A mechanistic study on the toxic effect of copper oxide nanoparticles in soybean (Glycine max L.) root development and lignification of root cells. Biological trace element research, 162(13), pp.342-352. https://doi.org/10.1007/s12011-0140106-5

Nair, R., Varghese, S.H., Nair, B.G., Maekawa, T., Yoshida, Y., \& Kumar, D.S. (2010). Nano particulate material delivery to plants. Plant science, 179(3), pp.154-163. https://doi. org/10.1016/j.plantsci.2010.04.012

Nguyen, T., Aparicio, M., \& Saleh, M. (2015). Accurate mass GC/LC-quadrupole time of flight mass spectrometry analysis of fatty acids and triacylglycerols of spicy fruits from the Apiaceae family. Molecules, 20(12), pp.2142121432. https://doi.org/10.3390/molecules201219779

Pollard, A.J., Powell, K.D., Harper, F.A., \& Smith, J.A.C. (2002). The genetic basis of metal hyper accumulation in plants. Critical reviews in plant sciences, 21(6), pp.539-566. https://doi.org/10.1080/0735-260291044359

Poonam, T., Tanushree, B., \& Sukalyan, C. (2013). Water quality indices-important tools for water quality assessment: a review. International Journal of Advances in chemistry, 1(1), pp.15-28. https://s3.amazonaws.com/academia. edu.documents

Raymond, J., Rakariyatham, N., \& Azanza, J.L. (1993). Purification and some properties of polyphenoloxidase from sunflower seeds. Phytochemistry, 34(4), pp. 927931. https://doi.org/10.1016/S0031-9422(00)90689-7

Rather, M.A., Dar, B.A., Sofi, S.N., Bhat, B.A., \& Qurishi, M.A. (2016). (Foeniculum vulgare): A comprehensive review of its traditional use, phytochemistry, pharmacology, and safety. Arabian Journal of Chemistry, 9, pp. S1574-S1583. https://doi.org/10.1016/j.arabjc.2012.04.011

Rico, C.M., Majumdar, S., Duarte-Gardea, M., Peralta-Videa, J.R., \& Gardea-Torresdey, J.L. (2011). Interaction of nanoparticles with edible plants and their possible implications in the food chain. Journal of agricultural and food chemistry, 59(8), pp.3485-3498. https://doi. org/10.1021/jf104517j

Rico, C.M., Peralta-Videa, J.R., \& Gardea-Torresdey, J.L. (2015). Differential effects of cerium oxide nanoparticles on rice, wheat, and barley roots: A Fourier Transform Infrared (FT-IR) micro spectroscopy study. Applied spectroscopy, 69(2), pp.287-295. https://doi.org/10.1366/14-07495

Saeidian, S., \& Ghasemifar, E. (2013). Effect of temperature on guaiacol Peroxidase of (Pyrus communis). International Letters of Natural Sciences, (5), 46-51. https://doi. org/10.18052/www.scipress.com/ILNS.5.46
Saison, C., Perreault, F., Daigle, J.C., Fortin, C., Claverie, J., Morin, M., \& Popovic, R. (2010). Effect of core-shell copper oxide nanoparticles on cell culture morphology and photosynthesis (photosystem II energy distribution) in the green alga, (Chlamydomonas reinhardtii). Aquatic toxicology, 96(2), pp.109-114. https://doi.org/10.1016/j. aquatox.2009.10.002

Seregin, I., \& Kozhevnikova, A.D. (2006). Physiological role of nickel and its toxic effects on higher plants. Russian Journal of Plant Physiology, 53(2), pp.257-277. https:// doi.org/10.1134/S1021443706020178

Siddiqui, M.H., Al-Whaibi, M.H., Firoz, M., \& Al-Khaishany, M.Y. (2015). Role of nanoparticles in plants. In Nanotechnology and Plant Sciences (pp. 19-35). Springer, Cham. https:// doi.org/10.1007/978-3-319-14502-0_2

Smirnova, G.V., Vysochina, G.I., Muzyka, N.G., Samoylova, Z.Y., Kukushkina, T.A., \& Oktyabrsky, O.N. (2010). Evaluation of antioxidant properties of medical plants using microbial test systems. World Journal of Microbiology and Biotechnology, 26(12), pp.2269-2276. https://doi. org/10.1007/s11274-010-0417-4

Soares, C., Branco-Neves, S., de Sousa, A., Pereira, R., \& Fidalgo, F. (2016). Eco toxicological relevance of nano$\mathrm{NiO}$ and acetaminophen to (Hordeum vulgare L.): combining standardized procedures and physiological endpoints. Chemosphere, 165, pp.442-452. https://doi. org/10.1016/j.chemosphere.2016.09.053

Sunkar, R. (2010). October. MicroRNAs with macro-effects on plant stress responses. In Seminars in cell \& developmental biology (Vol. 21, No. 8, pp. 805811). Academic Press. https://doi.org/10.1016/j. semcdb.2010.04.001

Suriyaprabha, R., Karunakaran, G., Kavitha, K., Yuvakkumar, R., Rajendran, V., \& Kannan, N. (2013). Application of silica nanoparticles in maize to enhance fungal resistance. IET nanobiotechnology, 8(3), pp.133-137. https://doi. org/10.1049/iet-nbt.2013.0004

Syu, Y.Y., Hung, J.H., Chen, J.C., \& Chuang, H.W. (2014). Impacts of size and shape of silver nanoparticles on Arabidopsis plant growth and gene expression. Plant physiology and biochemistry, 83, pp.57-64. https://doi. org/10.1016/j.plaphy.2014.07.010

Taiz, L., Zeiger, E., Møller, I.M., \& Murphy, A. (2015). Plant physiology and development. https://www. forskningsdatabasen.dk/en/catalog/2524903221

Tarrahi, R., Khataee, A., Movafeghi, A., Rezanejad, F., \& Gohari, G. (2017). Toxicological implications of selenium nanoparticles with different coatings along with $\mathrm{Se}^{4+}$ on (Lemna minor). Chemosphere, 181, pp.655-665. https:// doi.org/10.1016/j.chemosphere.2017.04.142

Tiwari, P.K., Singh, A.K., Singh, V.P., Prasad, S.M., Ramawat, N., Tripathi, D.K., Chauhan, D.K., \& Rai, A.K. (2019). Liquid 
assisted pulsed laser ablation synthesized copper oxide nanoparticles (CuO-NPs) and their differential impact on rice seedlings. Ecotoxicology and Environmental Safety, 176, pp.321-329. https://doi.org/10.1016/j. ecoenv.2019.01.120

Torbati, S. (2018). Phytotoxicological Effects of Bulk-NiO and NiO Nanoparticles on Lesser and Giant Duckweeds as Model Macrophytes: Changes in the Plants Physiological Responses. Iranian Journal of Toxicology, 12(4), pp.3139. http://ijt.arakmu.ac.ir/article-1-690-en.pdf

Tripathi, D.K., Singh, S., Singh, S., Pandey, R., Singh, V.P., Sharma, N.C., Prasad, S.M., Dubey, N.K., \& Chauhan, D.K. (2017). An overview on manufactured nanoparticles in plants: uptake, translocation, accumulation and phytotoxicity. Plant Physiology and Biochemistry, 110, pp.2-12. https://doi.org/10.1016/j.plaphy.2016.07.030

Tripathi, D.K., Singh, S., Singh, V.P., Prasad, S.M., Chauhan, D.K., \& Dubey, N.K. (2016). Silicon nanoparticles more efficiently alleviate arsenate toxicity than silicon in maize cultivar and hybrid differing in arsenate tolerance. Frontiers in Environmental Science, 4, p.46. https://doi. org/10.3389/fenvs.2016.00046

Velikova, M., Bankova, V., Sorkun, K., Houcine, S., Tsvetkova, I., \& Kujumgiev, A. (2000). Propolis from the Mediterranean region: chemical composition and antimicrobial activity. Zeitschrift für Naturforschung C, 55(9-10), pp.790-793. https://doi.org/10.1515/znc-2000-9-1019

Wang, X., Han, H., Liu, X., Gu, X., Chen, K., \& Lu, D. (2012). Multi-walled carbon nanotubes can enhance root elongation of wheat (Triticum aestivum) plants. Journal of Nanoparticle Research, 14(6), p.841. https://doi. org/10.1007/s11051-012-0841-5
Watanabe, S., Kojima, K., Ide, Y., \& Sasaki, S. (2000). Effects of saline and osmotic stress on proline and sugar accumulation in (Populus euphratica) in vitro. Plant Cell, Tissue and Organ Culture, 63(3), p.199. https://doi. org/10.1023/A:1010619503680

Wei, L., Thakkar, M., Chen, Y., Ntim, S.A., Mitra, S., \& Zhang, X. (2010). Cytotoxicity effects of water dispersible oxidized multiwalled carbon nanotubes on marine alga, Dunaliella tertiolecta. Aquatic Toxicology, 100(2), pp.194-201. https://doi.org/10.1016/j.aquatox.2010.07.001

Yang, L., \& Watts, D.J. (2005). Particle surface characteristics may play an important role in phytotoxicity of alumina nanoparticles. Toxicology Letters, 158(2) pp.122-132. https://doi.org/10.1016/j.toxlet.2005.03.003

Yruela, I. (2005). Copper in plants. Brazilian Journal of Plant Physiology, 17(1), pp.145-156. https://doi.org/10.1590/ S1677-04202005000100012

Zafar, H., Ali, A., Ali, J.S., Haq, I.U., \& Zia, M. (2016). Effect of $\mathrm{ZnO}$ nanoparticles on Brassica nigra seedlings and stem explants: growth dynamics and antioxidative response. Frontiers in plant science, 7, p.535. https:// doi.org/10.3389/fpls.2016.00535

Zhang, P., Cui, H.X., Zhang, Z.J., \& Zhong, R.G. (2008). Effects of nano- $\mathrm{TiO}_{2}$ photo semiconductor on photosynthesis of cucumber plants. Chinese Agricultural Science Bulletin, 24 pp.230-233. http://en.cnki.com.cn/Article_en/ CJFDTotal-ZNTB200808051.htm 